\title{
A RECEPÇÃO DOS PRODUTOS DE MÍDIA E SEU USO COMO FERRAMENTA NA AGRICULTURA FAMILIAR EM PONTA GROSSA/PR
}

\section{THE RECEPTION OF MEDIA PRODUCTS AND ITS USE AS A TOOL IN FAMILY FARMING IN PONTA GROSSA, PARANÁ, BRAZIL.}

\author{
João Carlos Dias de Oliveira ${ }^{1}$
}

\begin{abstract}
RESUMO
O presente artigo discute o uso da comunicação de massa pelo agricultor familiar ponta-grossense como uma ferramenta na busca de informações que sejam úteis para a atividade produtiva. $\mathrm{O}$ trabalho foca três aspectos: a produção feita para o meio, a recepção dada pelo produtor e o papel da comunicação no seio da sociedade. Foram feitas entrevistas, através de formulários de pesquisa com 60 pequenos produtores e analisadas produções voltadas para a comunicação rural em rádio, jornais e televisão. As reflexões teóricas são sustentadas por autores que discutem a comunicação a partir da sua importância e das relações entre emissão e recepção das mensagens midiáticas. A constatação final é de que o público estudado tem acesso aos principais canais midiáticos e conhecimento das formas mais populares de produção para o meio. No entanto, não é prática corrente entre eles o uso da mídia como uma ferramenta dentro da atividade rural.
\end{abstract}

Palavras-chave: Comunicação rural. Agricultor familiar. Produção midiática.

\begin{abstract}
This article discusses the use of mass communication by the family farmer in Ponta Grossa as a tool in the search for information that may be useful to agricultural activity. The study focuses three aspects: the production and its relation with the environment, the agricultural producer's reception and the role of communication in society. Interviews were made with the help of questionnaires with 60 small producers and media productions oriented to communication in rural areas in radio, newspapers and television were analyzed. The theoretical reflections are supported by authors that discuss communication, from its importance and from the relationship between emission and reception of mass media messages. The conclusion is that the community studied has access to most of the media channels and knows the most popular ways of media production of subjects of its interest. However, it is not a common practice between them the use of media as a tool in rural activity.
\end{abstract}

Keywords: Rural communication. Family farmer. Media production.

1 Mestre em Ciências Sociais Aplicadas pela UEPG. Atualmente é coordenador do curso de Publicidade do Cescage e professor de jornalismo da Faculdade Santa Amélia (SECAL). E-mail: diasjc67@hotmail.com 


\section{INTRODUÇÃO}

O presente artigo tem como objeto de estudo as relações entre o agricultor familiar e a produção midiática para o meio rural, ou seja, como esses trabalhadores utilizam o meio e qual é a produção da mídia para o público em questão. $\mathrm{O}$ estudo tem como foco o pequeno produtor rural de Ponta Grossa. Para pesquisá-lo, foi utilizado o conceito de agricultor familiar, que, segundo Schneider (2003), é um agricultor que vive e trabalha em pequenas áreas, utilizando mão de obra familiar e com a produção voltada para o consumo e a geração de renda. Rubelo (2001) define "agricultor familiar" como aquele que baseia suas atividades no trabalho da família. Lamarche (1993, p. 15) diz que a propriedade e o trabalho estão "intimamente ligados à família". O autor destaca ainda outro ponto característico bastante importante, que é a transmissão da terra de geração para geração, o que dá continuidade à atividade agrícola, com o crescimento ou a redução do patrimônio. Também será usado o termo "pequeno produtor", mas apenas como sinônimo de agricultor familiar.

Considera-se, para a pesquisa, a ideia de que a produção vai além do trabalho manual. Isso vale para toda atividade, seja urbana ou rural. Um fator determinante para o sucesso ou mesmo para a sobrevivência em qualquer ramo é o conhecimento. Para adquiri-lo, é necessário contar com subsídios da comunicação, seja face a face, seja através de mediações.

Outros objetivos mais específicos buscaram reconhecer os tipos de informação e temas pelos quais o agricultor familiar ponta-grossense mais se interessa; quais os meios de comunicação que utiliza e o que busca nos informativos.

De acordo com os levantamentos teóricos, a comunicação é um dos elementos mais importantes do desenvolvimento social, tanto para o convívio como para a cultura e o trabalho. Assim, a comunicação rural pode ter um papel preponderante enquanto ferramenta e indicador de aprendizado e tomada de decisões na pequena propriedade.

Além da fundamentação teórica, para a efetivação do trabalho foram ouvidos 60 agricultores familiares, representando todas as comunidades rurais do município, sobre a utilização que eles fazem dos meios de comunicação. Também foram realizadas entrevistas em emissoras de rádio sobre o tema e foi feita a análise do conteúdo da agenda de rádios, jornais e televisão. $\mathrm{O}$ objetivo foi levantar elementos para o desenvolvimento de tal trabalho.

Neste sentido, para o desenvolvimento da pesquisa, foi adotada a análise com a verificação textual de questões abertas e fechadas dentro do universo quantitativo definido. A proposta segue os preceitos de tal técnica na qual, segundo Bardin (1977), há um procedimento sistemático e objetivo da descrição do conteúdo analisado. A análise, segundo o autor, também pode ser de significado, o que foi adotado na verificação da utilização dos MCM no presente artigo.

As diferentes possibilidades e abordagens, como o uso de meios de comunicação, posse de meios eletrônicos e aplicação de conhecimentos na atividade rural também podem fazer parte da análise de conteúdo. Bardin (1977) destaca que a análise de conteúdo tem grande disparidade de formas, adaptando-se às necessidades, quando aplicada ao campo de comunicação. "É um conjunto de técnicas de análise das comunicações". (BARDIN, p. 31).

O levantamento feito é quantitativo e qualitativo, partindo do conceito de Richardson (1989). Para o autor, o método quantitativo caracteriza-se pelo emprego da quantificação na coleta e tratamento dos dados. Pode ser aplicado para descobrir e classificar a relação entre variáveis, bem como na investigação da relação de casualidade entre os fenômenos. Ainda segundo o autor, a pesquisa com os agricultores familiares de Ponta Grossa também pode ser considerada qualitativa, na medida em que apresenta perguntas abertas e observação de variáveis importantes para determinar os fatores que levaram ao resultado final.

\section{A COMUNICAÇÃO NO COTIDIANO SOCIAL}

O homem ingressou na era da comunicação de massa no século XIX, com o início dos jornais para a população em geral e da mídia elétrica, como o telégrafo. Mas a verdadeira transição dos meios eletrônicos ocorreu no século $\mathrm{XX}$, com o cinema, o rádio e a televisão, chegando, agora, à sociedade informatizada. Tal processo não se trata, na avaliação de Defleur e Ball-Rokeach (1993), de transição, mas de acumulação de conhecimentos que formam os sistemas de comunicação. 
De acordo com Thompson (2002), o desenvolvimento dos meios de comunicação teve grande impacto na automação social. Na comunicação face a face, o conhecimento era local e transmitido de geração a geração, através do intercâmbio oral e adaptado às necessidades da vida. $\mathrm{O}$ conhecimento acabava sendo mais limitado geograficamente e até temporalmente. O desenvolvimento dos sistemas mediados de comunicação mudou essa realidade e criou novas formas de relacionamentos sociais e interações, tanto espaciais como temporais. Se no passado era, portanto, possível a produção sem um maior intercâmbio de comunicação, atualmente a realidade tem outros contornos. Para Thompson (2002), o processo de formação do self se torna mais dependente das formas mediadas de comunicação.

Dessa forma, Kellner (2001) destaca que não se deve pensar no público como uma massa sem capacidade de pensar ou agir criticamente. Para o autor, a mídia manipula, sim, mas também sofre um processo de "manipulação" e uso do poder da própria mídia. Isso porque os meios se inspiram nas inquietações do público e se tornam parte de um circuito cultural. Os textos dos veículos de comunicação expressam experiências sociais.

\section{COMUNICAÇÃO RURAL}

A comunicação midiática de informações para o meio rural ainda é muito mais voltada para a agricultura empresarial e mais utilizada por grandes produtores. O estudo feito por Boteon (2004), embora focado na internet, é ilustrativo, pois demonstra que é na agricultura empresarial que mais se utiliza a informação mediada. $\mathrm{O}$ novo meio corre o risco de apresentar mais uma forma de exclusão da agricultura familiar. Para a autora, a informação é muito importante hoje para as tomadas de decisão do setor agropecuário.

Boteon (2004) destaca que, em 2003, apenas $4 \%$ do meio rural nacional tinha acesso a informações agropecuárias via internet. Do total, 92\% eram produtores ou administradores da propriedade, com curso superior. Apenas 21\% tinham receita bruta anual abaixo de R\$ 100 mil, o que revela que são grandes produtores que utilizam a ferramenta.

De certa forma, a internet facilitou a distribuição da informação, ampliando a atuação de intermediários.
Antes, o trabalho era feito basicamente por meios impressos, TV ou rádio; agora ocorre também digitalmente, com mais agilidade e baixo custo.

De acordo com Bordenave (1985), em grande medida, o desenvolvimento rural gira ao redor da comunicação, visto que os agricultores necessitam dela para tomar suas decisões de produção e convivência. O autor lembra que a comunicação rural é um processo mais amplo do que a mera informação agrícola. A tomada de decisões na agricultura é de grande importância. O produtor deve, constantemente, tomar decisões próprias sobre o uso da terra, tipos de culturas que serão adotadas, emprego de mão de obra, utilização de tecnologia, investimento de capital e venda de produtos. E a agricultura não depende apenas das suas decisões, mas também de medidas de outras empresas ou governos, que apoiam o sistema de produção ou que utilizam seus produtos. Segundo Bordenave (1985, p. 20-21),

A decisão baseia-se em três fatores: querer, saber e poder. A comunicação influi decisivamente sobre os três fatores da decisão. Os agricultores vão querer adotar uma inovação se sabem que ela existe e quais são suas consequências; poderão executá-la se aprendem como fazer, isto é, os procedimentos correspondentes. A incerteza que rodeia o agricultor só pode ser reduzida usando seu antídoto fundamental: a informação.

A conclusão que se pode tirar do pensamento de Bordenave (1985) é de que o agricultor, além de contar com fatores de produção, pode ter a seu favor outro item muito importante, que é a informação. Ele considera que, sem ela, suas decisões estariam sujeitas à incerteza e à improvisação.

\section{INSERÇÃO SOCIAL E O UNIVERSO RURAL}

Corcuff (2001) destaca que os indivíduos se inter-relacionam não apenas face a face, mas num complexo universal mais global. Nesse caso, devido a espaços temporais e geográficos, a mediação se apresenta como solução. Para Feliciano et al. (2004), os agricultores familiares precisam agregar conhecimento para gerir o negócio rural. Dessa forma, o domínio da informação se torna essencial. Por outro lado, os autores lembram que os geradores de informação 
devem ter consciência do papel da atividade, prestando informações confiáveis e consistentes.

De acordo com Thompson (2002), o ser humano está constantemente remodelando as suas habilidades, capacidades e aumentando o conhecimento, testando o que sente, o que gosta e expandindo os horizontes das experiências. Sempre está ampliando os conhecimentos pelas mensagens, usando, assim, os produtos da mídia, mesmo que a produção seja feita para um número indefinido de receptores e, na maior parte dos casos, em se tratando de meio rural, de sentido único, ou seja, do emissor para o receptor.

É bem possível que, com as ferramentas de comunicação, o agricultor familiar possa incrementar suas atividades e formas de trabalhar na propriedade. Pela comunicação, os indivíduos vão poder se ligar a outros produtores e à cadeia produtiva. Como colocam Defleur e Ball-Rokeach (1993), indivíduos, como sistemas sociais, criam relacionamentos de dependência com a mídia. Tal relação busca uma compreensão de fenômenos e orientação cotidiana, entre os quais, os aspectos produtivos e econômicos.

Canclini (1999) afirma que as estruturas tradicionais, como partidos, associações e grupos, muitas vezes perdem a sua eficácia. Sendo assim, o paradigma da agricultura familiar, calcado apenas em hábitos e costumes familiares, tem muita dificuldade de sobreviver no modus operandi dos sistemas de produção e comercialização dominantes na atualidade. A necessidade de gerar renda na propriedade passa obrigatoriamente pela capacidade de se conhecer melhor o negócio, dentro e fora da propriedade. Figueiredo e Giangrande (1999) consideram que quem quiser estar preparado para enfrentar satisfatoriamente a globalização pela qual passa o mundo atualmente tem que necessariamente transformar sua vida em um constante aprendizado.

A ocupação profissional do meio rural, eminentemente agrícola, acaba por caracterizar a população, como destaca Martins (1981). Há uma preponderância também da natureza, que escapa ao controle do agricultor e condiciona sua vida. Solari entende, também, que a sociedade rural tende a ser mais homogênea em suas relações psicossociais. Tem ainda maior proporção de filhos que seguem a mesma profissão dos pais, na qual pesa também o êxodo rural. Significa que quem fica no campo, via de regra, vai atuar na produção agropecuária.
Grossi e Silva (2002) dizem que, a partir da década de 1980, começou a surgir uma nova conformação do meio rural brasileiro, com a produção de commodities e novas atividades localizadas em nichos especiais, incluindo piscicultura, horticultura, floricultura, fruticultura e criação de pequenos animais. Isso gera uma nova estrutura produtiva, que pede novos conhecimentos, ainda que aliados aos tradicionais. Para Callou (2002), as alterações que podem dar maior sustentação ao pequeno produtor passam pela reestruturação da formação dos profissionais das Ciências Agrárias, o que melhoraria as formas de extensão rural. Assim, a comunicação rural também deve saber como trabalhar com as necessidades, sobretudo da agricultura familiar.

\section{O PAPEL MIDIÁTICO NO ESPAÇO SOCIAL}

Uma das dificuldades em inserir o agricultor familiar na contemporaneidade, com o excesso de informação de nossos dias, tomando como base a comunicação formal existente, é tornar acessível a mensagem a esse público. Disponibilizar programas de televisão, rádio, internet e outras formas de comunicação pode não ser tão difícil quanto melhorar a decodificação dos códigos disponibilizados. Se forem colocadas informações das bolsas de valores, por exemplo, baseadas na linguagem do "economês", para um agricultor com baixa escolaridade, provavelmente ele não vai entender grande coisa. "O indivíduo precisa conhecer os códigos para entender a mensagem", observa Thompson (2002, p. 29). Coelho Netto (2003) diz que uma mensagem será ou não significativa de acordo com o repertório ou conhecimento do receptor para interpretá-la. Thompson (2002) reforça ainda que a recepção dos produtos da mídia se sobrepõe a outras atividades. A importância dada aos meios de comunicação vai depender exatamente das maneiras como as mensagens vão se relacionar com aspectos de suas vidas.

$\mathrm{Na}$ atual estrutura social da agricultura familiar, ainda pesa muito a valorização de como são feitas as coisas na prática. O conhecimento é repassado de geração para geração, o que demanda um esforço intelectual de aprendizagem, que está além do esforço físico das atividades diárias. Mas isso não quer dizer que esse indivíduo está totalmente fechado 
para novidades externas. Se novas práticas derem resultados, o produtor as levará em consideração. No caso de estagnação da forma de trabalho, as chances de ele se manter na atividade são mínimas. Lamarche (1993) considera que, no modelo econômico atual, uma exploração familiar terá dificuldades de reprodução ou pode até desaparecer se continuar dependente do seu modelo original, sem adaptar-se ao mercado. Por outro lado, Lamarche (1993) também considera importante o patrimônio sociocultural dos produtores, sem o qual eles também podem deixar de existir.

\section{AGRICULTOR FAMILIAR COMO SUJEITO}

O desenvolvimento da busca da comunicação passa necessariamente por um despertar do interesse do pequeno produtor em usar a mídia como ferramenta. Capacitado para decidir, o receptor, decodificador da mensagem (no caso, o agricultor familiar) deseja e pode selecionar o que é importante para ele. Quer entender e avaliar para poder decidir se aceita ou não o que lhe é proposto e aplicar o que acha válido da mensagem, segundo Bordenave (1985).

A adoção de novos modelos é uma ação difícil, mas possível na maioria dos casos, e a comunicação rural, no verdadeiro sentido de comunicar, pode ser uma ferramenta eficaz. Segundo Bordenave:

Talvez a função mais básica da comunicação seja a menos frequentemente mencionada: a de ser o elemento formador da personalidade. Sem comunicação, de fato, o homem não pode existir como pessoa humana. (1985, p. 26).

Importante destacar, mais uma vez, a discussão sobre recepção. Thompson (2002) diz que se deve abandonar a ideia de que os espectadores, ouvintes ou leitores são receptores passivos de mensagens. A recepção também não acontece sem problemas ou críticas. Na maior parte das vezes, quem consome os produtos da mídia não vai apenas receber a mensagem e absorvê-la sem questionamentos. Há um self formado, individual e coletivo, que ajudará na escolha e absorção dos produtos midiáticos.

Sousa (2002) lembra que a primeira ideia que surge é a de que há uma predominância do emissor em relação ao receptor. Neste sentido, haveria um emissor genérico "macro", os veículos de comunicação, e um receptor "micro". O autor refuta tal ideia e destaca que é preciso pensar no homem como indivíduo e não apenas como uma massa inerte. $\mathrm{O}$ receptor atual se individualiza no contexto de espaço e tempo. Dessa forma o receptor, ressalta Souza (2002), deixa de ser visto como consumidor necessário de produtos culturais ou é massificado apenas porque consome. É um receptor em situações e condições específicas. Assim, os veículos precisam ser compreendidos no processo em que atuam.

É relevante diferenciar, por exemplo, o acesso do agricultor familiar à televisão, ao rádio e ao uso que faz de tais meios. Será que trazem informações de interesse para a atividade produtiva? E será que são realmente úteis? Ou, por outro lado, os produtos de mídia são usados apenas para o lazer? O viés da recepção deve ser visto além da mensagem passada por um emissor e seus interesses. É preciso compreender o universo de quem está disposto a consumir e em que medida ele tem interesse na absorção da mensagem. No final, a decisão é do agricultor familiar, como indivíduo e ser social.

\section{PROdUÇÃO MEDIAdA PARA O MEIO RURAL}

De acordo com Oliveira (1989), a informação rural ganhou novo impulso com a organização da extensão rural, na década de 1940 (implantada em 1948 no Brasil). No início, o público principal era formado pelas comunidades rurais. Vinte anos mais tarde, no final da década de 1960, tinha outra conformidade. Com a Revolução Verde, a comunicação para o meio rural passou a concentrar sua atenção em pessoas que exploravam comercialmente suas propriedades, e não apenas nos moradores da zona rural.

Nos anos 1970 e 1980, os grandes meios de comunicação começaram a abrir espaço para a área da comunicação rural. Também o rádio cedeu grande tempo, devido ao crescimento do número de emissoras e audiência no meio. Oliveira (1989) conta que a criação do Globo Rural, pela Rede Globo, por exemplo, se deu pela constatação da existência de 4 milhões de aparelhos de TV no campo e um grande potencial de investidores para a publicidade. De acordo com o autor, há uma ruralização da comunicação, devido ao descobrimento do público potencial. 
O problema é que a produção discursiva para o meio rural segue a lógica do agronegócio e sua importância no processo de acumulação capitalista. Os cadernos rurais dos jornais diários, por exemplo, falam principalmente para o público participante de tal setor, com temas e abordagens que concordam com o pensamento do próprio público leitor.

Mas mesmo que apresente significativas falhas, a produção midiática preserva sua necessidade. Em grande medida, a comunicação auxilia no desenvolvimento rural, visto que os agricultores necessitam de informações para tomar decisões. A população rural, segundo Bordenave (1985), concentra sua vida e seu comportamento em uma atividade especial, muito complexa e marcante, que é a agricultura. Conforme o autor, o agricultor e sua família trabalham num ambiente formado pelo clima, a topografia do solo, a flora e a fauna. Suas decisões são influenciadas por diversas organizações e instituições que formulam a política agrária e fornecem crédito.

Fernández e Amtmann (2007) mostram que a recepção e aceitação de novidades no meio rural passam por fatores como conhecimento e inter-relação com líderes que acabam conduzindo o processo. A adoção de inovações se dá por diferentes etapas, como conhecer o que é proposto, ser persuadido a aceitar, decidir se deseja adotar as novas técnicas e passar a usá-las, rechaçá-las, ou mesmo voltar às técnicas anteriores. Os autores também destacam que o desenvolvimento rural não deve se pautar apenas na atividade agrícola. A melhora da saúde, educação, conservação do meio ambiente, seguridade social, entre outros componentes, é necessária.

Defleur e Ball-Rokeach (1993) dizem que a mídia pode influenciar na tomada de decisões, ou, pelo menos, na construção subjetiva de pensamentos sobre temas. Há uma influência seletiva da mensagem. Primeiro o produtor pode tomar conhecimento de uma novidade através de alguma forma de comunicação de massa. Daí vai decidir o que fazer. A questão da adoção ou não depende de fatores, às vezes parecidos, incluindo a identificação. Personagens ouvidos na notícia que pertencem à mesma categoria social influenciam a atenção do receptor.

Alguns meios ainda chegam com mais facilidade e podem exercer um papel determinante na disseminação de informação para a agricultura familiar. Deve-se destacar, como exemplo, o rádio, presente em mais de $90 \%$ dos lares brasileiros. Ortriwano (1985) aponta características relevantes do rádio como veículo e afirma ser este o mais popular e de maior alcance público. Ela lembra que, muitas vezes, "é o único a levar informações para populações que vivem em locais mais distantes", o que reforça a ideia em relação ao pequeno produtor rural. A autora também destaca a questão da linguagem oral, que dispensa maiores conhecimentos da linguagem escrita, e torna o rádio viável para as pessoas mais simples. Assim, permite que seja ouvido enquanto o produtor desenvolve outras atividades. Defleur e Ball-Rokeach (1993) dizem que as pessoas podem ouvir o rádio enquanto estão fazendo uma série de outras atividades.

Mas isso não descarta outras possibilidades, como a televisão e a mídia impressa, essa ainda vista como um desafio, algo que pode ser alcançado, desde que tenha linguagem e utilidade acessíveis ao agricultor familiar.

Tais discussões demonstram que a comunicação é um fator central na formação individual e social. Ela está presente no cotidiano de todas as pessoas, sejam do meio urbano ou rural. Não é possível pensar em relações sociais sem se comunicar e estar informado sobre o que acontece nas proximidades e em locais distantes.

\section{ANÁlise DOS VEÍCULOS DE COMUNICAÇÃO}

Com base nos fundamentos teóricos até aqui apresentados, foi então feita uma análise dos veículos de comunicação, levando em consideração o discurso e a oferta. O objetivo foi verificar como o emissor enxerga o público a quem dirige a mensagem e qual é o produto oferecido ao agricultor familiar. Para isso, foram feitas pesquisas da mídia impressa, rádio e televisão.

A metodologia adotada para análise partiu de uma pesquisa documental de jornais e da análise editorial de programas específicos de rádio e televisão, utilizados como amostragem de produtos, ao menos em tese, disponíveis para o agricultor familiar. Essa busca direta trata-se do que Luna (1996) destaca como fonte primária. No caso do rádio, também foi realizado um levantamento nas emissoras, através de formulários, para entender por que elas não 
trabalham com a comunicação rural em Ponta Grossa. Em todos os casos foram feitas análises qualitativas e quantitativas das matérias publicadas. $\mathrm{O}$ objetivo foi de avaliar o conteúdo das notícias e como são passadas ao receptor.

Os aspectos observados foram as formas de agendamento das notícias, critérios de noticiabilidade, discurso adotado nos textos e apresentações, relevância social, atores envolvidos, linguagem adotada e tratamento do receptor.

\subsection{O discurso jornalístico dos cadernos rurais}

A primeira análise apresentada é do jornalismo impresso que, conforme demonstra a pesquisa, tem pouca procura por parte dos agricultores familiares entrevistados. Preços, falta de hábito de leitura, dificuldade de distribuição para o meio rural, linguagem utilizada e assuntos tratados são alguns dos aspectos que podem ser colocados como desmotivadores do veículo.

Foi analisado o agendamento de três jornais diários que circulam no município e possuem cadernos rurais: Diário dos Campos, de Ponta Grossa, com o caderno Agribusiness; Gazeta do Povo, de Curitiba, com o Caminhos do Campo e O Estado de São Paulo, com o suplemento Agrícola. Tanto o Agribusiness como o Agrícola têm edições semanais, já o Caminhos do Campo circula quinzenalmente. Ambos com circulação de tais cadernos em 2006. Todos tratam de agropecuária, mas com um foco preferencial na chamada agricultura empresarial.

Os cadernos foram acompanhados durante dois meses, período que corresponde a oito edições dos cadernos Agribusiness e Agrícola e cinco edições do Caminhos do Campo.

No período analisado, ficou claro que há uma preferência pelos assuntos do agronegócio empresarial, que, no Brasil, prioriza a pecuária de corte, gado leiteiro, produção de grãos (milho, soja e arroz), café e cana-de-açúcar. Não foram considerados pequenas notas, agendas, calendários, entre outros. No caderno Agrícola, de O Estado de São Paulo, 63\% das matérias se enquadram nas classificações acima, outras $12 \%$ são matérias sobre políticas agrícolas ou tecnologias que interessam ao grande produtor e $8,7 \%$ relacionadas à agroindústria. $\mathrm{O}$ jornal publicou $10,9 \%$ de notícias oficiais - governo, pesquisa, entre outros e apenas 5,4\% de notícias que, de alguma forma, podem interessar ao pequeno produtor, como produção de frutas ou olericultura. A definição do interesse do agricultor familiar parte dos levantamentos que mostram a forma de produzir e as culturas trabalhadas nas propriedades familiares dos entrevistados.

No caderno Agribusiness, do Diário dos Campos, a análise apresenta maiores dificuldades, uma vez que o encarte foi produzido por apenas uma jornalista, com apoio de agências de notícias, e sem uma linha editorial mais definida de preferência pelo grande, médio ou pequeno produtor. Ainda assim, os resultados mostram maior favorecimento editorial para a agricultura empresarial e nenhum enfoque proposital à produção familiar, aliás, a palavra não aparece na fala da redatora. $\mathrm{O}$ enfoque direto ao agronegócio foi encontrado em 34,8\% das matérias e o mesmo índice foi encontrado para a pecuária. Outras culturas, pesquisa e notícias oficiais são $24,2 \%$ dos assuntos, enquanto que $6,2 \%$ destacam o agronegócio da pequena e média propriedade. Referências sociais da agricultura familiar não aparecem.

O caderno Caminhos do Campo, no período avaliado, foi o veículo que apresentou maior preocupação social e destaque ao agricultor familiar, já que trata de matérias ambientais e relativas às questões da pequena propriedade, mas, ainda assim, o agronegócio empresarial ganha de longe maior espaço. As commodities, pecuária e outras atividades da grande agricultura ficam com $55 \%$ do espaço editorial. Apenas 2,5\% delas tratam de assuntos políticos da grande propriedade. No entanto, $10 \%$ tratam da agricultura familiar, com destaque para propostas do desenvolvimento dela. Assuntos de médios produtores ficam com 7,5\% do espaço (considerando culturas que regularmente são trabalhadas por tal público). A pesquisa e assuntos de políticas agrícolas ocupam $25 \%$ do espaço.

Fica evidente, na análise, que a construção do discurso dos cadernos não tem como foco a agricultura familiar, ou um desenvolvimento social rural, como aponta Bordenave (1985) o que seria a função da comunicação. Apenas em 10\% das matérias, de um único caderno, o Caminhos do Campo, é que se encontra algum discurso voltado para o pequeno produtor. Intencionalmente, ou não, os cadernos 
rurais priorizam seu agendamento nos temas do grande produtor, commodities e gado de corte.

A linguagem adotada, na qual prevalecem termos técnicos e mercadológicos, também pode ser considerada uma barreira para o agricultor familiar.

\subsection{O rádio no meio rural}

Apesar de estar presente em 96,7\% dos lares dos produtores familiares entrevistados, o rádio é pouco utilizado para a obtenção de informações rurais. Apenas $15,5 \%$ dos agricultores se utilizam do meio para tal fim. Uma entrevista feita com representantes das oito emissoras de Ponta Grossa demonstra que não é propriamente alguma deficiência do veículo que causa desinteresse do receptor em obter informações através do rádio, mas a quase ausência de informativos agropecuários nas rádios locais. Atualmente, apenas um informativo diário, de 10 minutos, produzido pelo Instituto Paranaense de Assistência Técnica e Extensão Rural (Emater-Pr), é veiculado em uma emissora, a Rádio Santana, AM. O fato foi constatado na pesquisa realizada em três rádios FM (Tropical, Mundi e FM 94) e nas cinco AM (Rádio Clube, Central, Santana, Difusora e CBN) da cidade.

O único programa presente, O Homem e a Ter$r a$, produzido pela Emater-Pr, é feito em Curitiba e distribuído para emissoras de todo o Paraná, que decidem o melhor momento de colocá-lo no ar. O seu público é o agricultor familiar. A Santana coloca o informativo das $6 \mathrm{~h} 30$ às $6 \mathrm{~h} 40$.

\subsection{A televisão}

A pesquisa também demonstrou que, entre os entrevistados, a televisão é o principal meio de comunicação utilizado pelo produtor de base familiar para saber o que está acontecendo no meio rural. O aparelho de TV está presente em 96,7\% dos lares dos agricultores familiares em questão. Do universo de 60 agricultores, 40 (66\%) citam esse meio como maneira de obter notícias agrícolas, sendo que 32, ou seja, $71,1 \%$ dos 40 , são espectadores do programa Globo Rural, da TV Globo. E os produtores entrevistados não são uma exceção. Mendes (2002) diz que a televisão é o meio de comunicação de maior penetração nos segmentos sociais. Em média, a população em geral assiste a mais de três horas diárias de TV, o que representa em torno de $20 \%$ do tempo que uma pessoa permanece acordada. Esse tempo cresce para quase quatro horas no fim de semana e ultrapassa 21 horas por semana.

Parece evidente que a penetração da televisão, hoje, também é grande no meio rural. Assim como o morador dos centros urbanos, o agricultor familiar usa o meio para o lazer ou nas horas de descanso. Quando se trata de buscar informação, a pesquisa demonstrou que a maior parte dos entrevistados continua preferindo o mesmo "eletrodoméstico de diversão". E o programa preferido é o Globo Rural.

Para entender como funciona a informação via televisão, foi realizada uma pesquisa de dois programas oferecidos ao produtor familiar ponta-grossense, o Globo Rural, da Rede Globo, transmitido para todo o Brasil, e o Caminhos do Campo, da Rede Paranaense de Comunicação (RPC), rede estadual de televisão afiliada à mesma Globo.

Ambos são dominicais. O Globo Rural tem uma hora de duração, das 8 às 9 horas. Já o Caminhos do Campo vai das $7 \mathrm{~h}$ às $7 \mathrm{~h} 30$. Foram observadas quatro edições dominicais do primeiro e quatro do segundo.

O Globo Rural está no ar desde 1980. De acordo com Gonçalves (2005), o programa tem contribuído para a divulgação da ciência do meio rural, ainda que haja críticas com relação à seleção dos assuntos. Segundo a autora, a qualidade técnica do programa causa atração e fidelidade do público. Gonçalves (2005) diz que o Globo Rural segue a lógica da televisão, meio que, para a autora, dá preferência para o espetacular e para assuntos muito próximos do público-alvo, para conseguir maior audiência e mais investimentos publicitários.

Nas edições analisadas do Globo Rural foi possível registrar que o programa segue um padrão de matérias mais longas, que podem variar de um até cinco minutos, notas inferiores a um minuto, divulgação de festas e eventos do meio rural, mercado agropecuário e especiais, que chegam a ocupar dois blocos. Agricultura, clima e meio ambiente estão presentes na programação.

O agendamento do Globo Rural segue a lógica da novidade nas matérias completas, com informações para o pequeno, médio e grande produtor. Os critérios de noticiabilidade, além da agenda, passam notadamente por lógicas de mercado, alertas aos 
produtores e exemplos considerados bons pela equipe que produz o programa. Não há uma análise de outros ângulos, que podem significar pontos negativos da opção pela cultura apresentada.

De uma maneira geral, nas edições analisadas, o público que se buscou envolver foi amplo, do pequeno ao grande produtor, mas sempre tendo em vista uma ideia favorável do mercado. Vale lembrar que o Globo Rural é nacional, portanto, nem todos os temas servem aos espectadores de Ponta Grossa.

Já o programa Caminhos do Campo, da Rede Paranaense de Comunicações, é feito com matérias produzidas por equipes da rede e um apresentador fixo, que também faz reportagens. São apresentados dois tipos de matérias, as factuais, de temas de momento, e de culturas que estão dando bom retorno financeiro. Também é mostrada uma agenda de festas e receitas. Há uma predileção em mostrar como se preparam pratos, assunto que geralmente fecha as matérias. Em quatro edições foram mostrados cinco, sempre com a dica de que podem ser encontrados no site da emissora. O programa não apresenta cotações, também não demonstra ter um critério lógico de agendamento. As edições são montadas com matérias enviadas pelas repetidoras espalhadas pelo Estado. O discurso se mostra extremamente favorável aos temas apresentados, tidos como excelentes negócios, sem haver qualquer questionamento. $\mathrm{O}$ agricultor familiar, geralmente, é apresentado como alguém bem-sucedido, que leva uma vida agradável, longe da agitação urbana.

\section{CONSUMO DA MÍDIA NA AGRICULTURA FAMILIAR}

Considerando a importância dos processos de comunicação no desenvolvimento de qualquer atividade humana, foi feita a pesquisa empírica para analisar de que maneira o agricultor familiar de Ponta Grossa usa os produtos de mídia como ferramenta de trabalho. Foram entrevistados, via formulário, 60 produtores rurais que se encaixam nos conceitos que definem os agricultores familiares.

Do universo total de pequenos produtores entrevistados, $16,7 \%$ têm até 35 anos (10 produtores), $48,3 \%$ têm entre 36 e 50 anos (29 produtores) e $35 \%$ acima de 50 anos (21 produtores). Observa-se, portanto, maior presença de pessoas do grupo de idade intermediária na posição de comando da propriedade, sejam homens e/ou mulheres.

\subsection{Nível escolar}

Entre os 60 agricultores familiares entrevistados, 28 têm o primeiro grau incompleto; 10 terminaram o primeiro grau, quatro têm o segundo grau incompleto, 12 o segundo grau completo, um produtor está cursando o terceiro grau e cinco disseram que têm nível superior.

Quadro 1: Nível escolar dos produtores entrevistados e de seus respectivos cônjuges, considerando que 53 disseram que são casados

\begin{tabular}{|c|c|c|}
\hline $\begin{array}{c}\text { NÍVEL } \\
\text { ESCOLAR }\end{array}$ & ENTREVISTADO & CÔNJUGE \\
\hline $\begin{array}{c}1^{\circ} \text { grau } \\
\text { incompleto }\end{array}$ & $46,7 \%$ & $47,2 \%$ \\
\hline $\begin{array}{c}1^{\circ} \text { grau } \\
\text { completo }\end{array}$ & $16,7 \%$ & $18,8 \%$ \\
\hline $\begin{array}{c}2^{\circ} \text { grau } \\
\text { incompleto }\end{array}$ & $6,7 \%$ & $7,6 \%$ \\
\hline $\begin{array}{c}2^{\circ} \text { grau } \\
\text { completo }\end{array}$ & $20 \%$ & $16,9 \%$ \\
\hline $\begin{array}{c}3^{\circ} \text { grau } \\
\text { incompleto }\end{array}$ & $1,6 \%$ & $9,5 \%$ \\
\hline $3^{\circ}$ completo & $8,3 \%$ & \\
\hline
\end{tabular}

Fonte: Pesquisa do autor

\subsection{Acesso à informação}

Procurou-se saber qual é o acesso que o agricultor familiar tem aos meios de comunicação. Quanto à disponibilidade, confirmou-se que o rádio e a televisão são os veículos mais presentes na vida dos pequenos produtores. Dos 60 entrevistados, $58(96,7 \%)$ disseram que têm pelo menos um aparelho de rádio em casa. $\mathrm{O}$ mesmo número foi encontrado em relação à televisão. Mas a metade dos agricultores entrevistados (50\%) utiliza antena parabólica. Eles alegam que o sinal de TV é ruim para ser captado por uma antena simples. Assim, ficam alheios às informações do Estado, já que a programação recebida é direta das emissoras "cabeça de rede", a maioria instalada em São Paulo e Rio de Janeiro. 
Já a mídia impressa está pouco presente no cotidiano dos produtores entrevistados. Apenas nove disseram que compram jornal ou revista regularmente. Outros dois afirmaram que assinam. No caso de jornais ou revistas específicos de assuntos da agropecuária, 12 disseram que compram ou recebem com regularidade (no segundo caso, informativos de cooperativas ou associações). Outro disse que assina uma revista agrícola. Assim, considerando compras, distribuição gratuita ou assinatura, 18,3\% dos pequenos produtores dizem fazer uso da mídia impressa para informação geral e 21,6\% para informações do meio rural.

Outros 15 produtores $(25 \%)$ disseram ainda que têm computador em casa e $10(16,6 \%)$ contam com internet. De maneira geral, a pesquisa demonstrou que o agricultor familiar, diferente do que ocorria há três ou quatro décadas, tem acesso à boa parte da tecnologia moderna presente no meio urbano. Uma casa em uma pequena propriedade rural conta, ou pode contar, com tudo aquilo que se encontra nos lares da classe média baixa das cidades.

Quadro 2: Acesso dos agricultores familiares aos veículos de comunicação

\begin{tabular}{|l|c|}
\hline VEÍCULOS & $\mathbf{\%}$ \\
\hline Rádio & $96,7 \%$ \\
\hline Televisão & $96,7 \%$ \\
\hline Antena parabólica & $50 \%$ \\
\hline Jornais e revistas & $18,3 \%$ \\
\hline Impressos especializados & $21,6 \%$ \\
\hline Computador & $25 \%$ \\
\hline Internet & $16,6 \%$ \\
\hline
\end{tabular}

Fonte: Pesquisa do autor

\subsection{Interesse pelos produtos midiáticos}

Entre os entrevistados, $45(75 \%)$ disseram que acompanham algum noticiário sobre agricultura, outros 15 (25\%) afirmaram que não. A televisão foi o veículo mais citado entre aqueles que acompanham o noticiário agropecuário. De 45 produtores que usam tal meio, 40 assistem a programas de TV sobre o tema, o que representa $88,9 \%$ do total. Sete utilizam o rádio, dois citaram revistas e um, jornal. O programa Globo Rural é o preferido, sendo lembrado 32 vezes; nove citaram a programação do
Canal do Boi (TV via satélite); cinco disseram que assistem ao Canal Rural (também por satélite); dois acompanham o SBT Rural e um disse que assiste ao programa Vida no Campo, produzido pela Empresa Paranaense de Assistência Técnica e Extensão Rural (Emater-PR) e transmitido pela Rede Vida. No caso do rádio, foi citado por dois agricultores o $O$ Homem e a Terra, programa diário, também da Emater-Pr, e de uma emissora de Irati, que não foi especificado. A ideia de reforçar propostas locais fica comprometida no momento em que se opta pela televisão, que tem a maior parte da produção feita de forma generalista, para todo território nacional. A opção por programas de televisão também mostra que há uma lógica do entretenimento no fato de se assistir aos programas, como foi observado em muitas respostas que destacam o aspecto "agradável" da produção. Ademais, reforça a utilização do meio, uma vez que $96,7 \%$ dos entrevistados têm televisão, contra 18,3\% que compram jornais, por exemplo.

Vale destacar que embora 10 agricultores afirmem ter internet em casa, nenhum citou a rede como uma fonte de informações. Essa mídia, portanto, como já era suposto, ainda está muito distante do agricultor familiar ponta-grossense.

Quadro 3: Produtores que acompanham os noticiários agropecuários e os veículos mais utilizados

\begin{tabular}{|l|l|}
\hline \multicolumn{2}{|c|}{ Acompanha os noticiários agropecuários } \\
\hline SIM: 45 entrevistados & NÃO: 15 entrevistados \\
\hline \multicolumn{2}{|c|}{ Veículos utilizados } \\
\hline Televisão & 40 entrevistados \\
\hline Rádio & 7 entrevistados \\
\hline Revista & 2 entrevistados \\
\hline Jornal & 1 entrevistado \\
\hline
\end{tabular}

Fonte: Pesquisa do autor

\subsubsection{Como utiliza as informações}

Dos 45 agricultores entrevistados que acompanham o noticiário agropecuário, 23 disseram que não utilizam tais informações nas atividades diárias, o que representa $51,5 \%$ do total. Somados aos 15 que não acompanham, são 38 , ou $63,3 \%$, que dizem não usar informações como uma forma de nortear, em algum momento, a produção. Dicas de plantio e manejo, além do uso de alguma sugestão 
repassada pela mídia, foram formas de aplicação citadas por nove produtores, ou seja, $20 \%$ dos 45 que fazem uso do noticiário. Outros quatro disseram que incorporam tais sugestões quando as consideram úteis; quatro afirmaram que se interessam por preços e comércio, e dois para se aperfeiçoarem na atividade. Apenas três entrevistados $(6,7 \%)$ disseram que fazem registros sistemáticos de informações, inclusive buscando aquilo que precisam para melhorar ou resolver problemas através da comunicação.

Quando o agricultor familiar responde que aproveita dicas e até experimenta algumas alternativas, quando acha determinada informação útil e se interessa por ela, ou quando busca se aperfeiçoar através de alguns assuntos da mídia, pode-se concluir também que ele não desconhece as possibilidades de comunicação. Assim é possível ampliar para 30\% o total de produtores familiares que usam a informação midiática em algum momento, o que ainda é um percentual baixo.

As informações são usadas na medida em que surgem necessidades. A busca ocorre nos momentos em que o produtor precisa resolver algum problema pontual. Mas na pesquisa observou-se também que alternativas ou notícias apresentadas pela mídia, ainda que num primeiro momento não estejam na pauta de prioridades do agricultor familiar entrevistado no presente trabalho, podem passar a interessar, a ponto de ele buscar saber mais sobre o assunto. Como cita Bordenave (1985), o desenvolvimento rural gira em torno da comunicação mediada, na medida em que o produtor precisa dela para tomar decisões.

A comunicação mediada, como é apresentada na fundamentação teórica, de uma forma ou outra, atua no conhecimento e tomadas de decisões. O que mostra a pesquisa é que, muitas vezes, o produtor não se dá conta de que ela pode e deve ser uma ferramenta frequente e até metodológica. Ainda assim, a comunicação participa da formação do self, junto com aspectos da tradição, como coloca Thompson (2002). E na medida em que as respostas mostraram uma seleção de questões pontuais de interesse, os agricultores familiares acabam fazendo uma seleção de mensagens, como citam Defleur e Ball-Rokeach (1993). Quer dizer, nem tudo interessa, mas aquilo que é importante chama a atenção de cada entrevistado, individualmente.
Quadro 4: Utilização das informações agropecuárias dentro da atividade, considerando apenas os 45 produtores que acompanham o noticiário

\begin{tabular}{|l|c|c|}
\hline \multicolumn{1}{|c|}{ Grupo de respostas } & Total & \% \\
\hline Não utiliza as informações & $23 *$ & $51,5 \%$ \\
\hline Dicas para a atividade & 9 & $20 \%$ \\
\hline Preços e mercado & 4 & $89 \%$ \\
\hline Quando acha útil & 4 & $89 \%$ \\
\hline Para aperfeiçoamento & 2 & $44 \%$ \\
\hline Registros sistemáticos & 3 & $67 \%$ \\
\hline
\end{tabular}

Fonte: Pesquisa do autor

*Somando os 15 que não acompanham, o percentual de não utilização chega a 63,3\%.

\subsection{Tomada de decisão}

Assim, se a comunicação não aparece como ferramenta central, outros aspectos apresentam maior importância na tomada de decisões, como produzir, por exemplo. No geral, 25 agricultores familiares plantam culturas de acordo com a tradição, o que representa $41,6 \%$ do total. Outros cinco $(8,3 \%)$ se pautam nas necessidades de consumo na propriedade; 21 (35\%) consideram preços e calendário como fator norteador da produção; seis (10\%) são integrados a cooperativas ou empresas, e trabalham para elas; dois $(3,3 \%)$ têm nas atividades atuais uma alternativa de renda e um $(1,6 \%)$ se baseia em sugestão de uma terceira pessoa.

A comunicação formal - ou dos meios de comunicação de forma geral - não foi citada como fator de ajuda na opção feita, embora as decisões tomadas através de preços ou a busca por alternativa de renda possam ser analisadas como provenientes da comunicação, face a face ou mediada.

Quadro 5: Como o agricultor familiar toma as decisões para produzir

\begin{tabular}{|l|c|c|}
\hline \multicolumn{1}{|c|}{ Tomada de decisão } & Total & \% \\
\hline Por tradição & 25 & $41,6 \%$ \\
\hline Pelo consumo & 5 & $83 \%$ \\
\hline Preços e mercado & 21 & $35 \%$ \\
\hline Integrados a empresas & 6 & $10 \%$ \\
\hline Alternativa de renda & 2 & $33 \%$ \\
\hline Sugestão de terceiros & 1 & $16 \%$ \\
\hline
\end{tabular}

Fonte: Pesquisa do autor 


\subsection{Avaliação dos meios de comunicação}

Por último, destaca-se aqui a avaliação dos produtores sobre os produtos de mídia, considerando os programas de rádio e televisão e a mídia impressa. Foi possível perceber que as respostas se pautaram mais nos veículos eletrônicos, provavelmente porque poucos fazem uso de outros meios.

De todos os entrevistados, $40(66,6 \%)$ disseram que é fácil entender a linguagem da mídia para o meio e 18 (30\%) disseram que não. Outros dois $(3,3 \%)$ não responderam.

Foi perguntado aos agricultores familiares como deveria ser um noticiário para o pequeno produtor. Dos 60 entrevistados, $22(36,6 \%)$ não souberam responder. Daqueles que responderam, sete disseram que seria importante trazer mais informações de interesse da agricultura familiar. Três temas tiveram seis opiniões: preços, tecnologias e orientações para o pequeno produtor. Apareceram três vezes os temas "cuidados com a lavoura" e "informações sobre programas de apoio" para o público em questão. Foram citadas, duas vezes cada, informações sobre culturas para pequenas áreas, novas oportunidades e técnicas de plantio. Uma vez, notícias sobre fruticultura e apicultura, além de políticas públicas para a agricultura familiar. Verifica-se que há uma heterogeneidade de interesse entre os produtores familiares.

Ainda nessa questão, vale destacar que os produtores familiares consideram importante a comunicação. Como também se trata de uma questão aberta, as respostas foram divididas em cinco grupos, sendo o primeiro de entrevistados que disseram que a comunicação não é importante. No segundo grupo foram colocadas as respostas daqueles que apenas consideram que há importância, mas não souberam ou quiseram especificar. O terceiro grupo englobou produtores que destacaram ser fundamental saber de preços e mercado para venda. No quarto, se encontram dois entrevistados $(3,3 \%)$ que disseram que sem se comunicar e saber o que acontece no meio é impossível trabalhar.

Outras respostas foram consideradas pontuais, ou seja, destacando um ou dois fatores da produção como um todo, mas que se assemelham. Estão nesse grupo os aspectos de melhoria das condições de determinada lavoura, informações de tecnologias, ajuda para o desenvolvimento da cultura, informações sobre pragas e cuidados com a lavoura. Um citou que procura saber seus direitos e dois apenas destacaram que é importante para saber mais. O resultado final da questão nem sempre fecha $100 \%$, já que alguns entrevistados deram mais de uma resposta.

A questão mostrou que há uma contradição entre o que pensa e o que faz o agricultor familiar participante da pesquisa, uma vez que apenas $11,6 \%$ dos entrevistados acreditam que a comunicação não é um fator importante na atividade agropecuária. Os outros $88,4 \%$ disseram que é importante estar informado. Apenas $25 \%$ destacaram a importância, sem explicar o porquê; 38,3\% apontaram o conhecimento de preços e do mercado como fator determinante; $3,3 \%$ avaliam que sem informação não é possível continuar na atividade e 53,3\% apontaram outros fatores, entre aqueles destacados acima.

Quadro 6: Avaliação dos agricultores familiares sobre as facilidades ou dificuldades de entender a comunicação rural

\begin{tabular}{|l|l|l|}
\hline De fácil entendimento & 40 & $66,7 \%$ \\
\hline Difícil de entender & 18 & $30 \%$ \\
\hline Não responderam & 02 & $3,3 \%$ \\
\hline Total & 60 & \\
\hline
\end{tabular}

Fonte: Pesquisa do autor

\subsection{Comunicação do Agricultor com os Produtos de Mídia}

A posição dos 60 agricultores familiares ponta-grossenses entrevistados frente aos veículos de comunicação é apenas de receptor, sem nenhuma interação. Apenas cinco (8,3\%) disseram que já se comunicaram com veículos atrás de informações ou para dar sugestões. Um desses três disse que já o fez várias vezes e de todas as formas, o segundo afirmou que só não usou a internet. O telefone foi a opção utilizada pelos outros três produtores. Nenhum procurou jornal, televisão ou rádio pessoalmente. 
Quadro 7: Já se comunicaram com os MCM e meios utilizados

\begin{tabular}{|c|c|}
\hline \multicolumn{2}{|c|}{ Comunicação com os MCM } \\
\hline Sim: $5(8,3 \%)$ & Não: $55(91,7 \%)$ \\
\hline Meios utilizados para se comunicar \\
\hline Carta & 2 \\
\hline Telefone & 5 \\
\hline Internet & 1 \\
\hline Pessoalmente & 0 \\
\hline
\end{tabular}

Fonte: Pesquisa do autor

\section{CONCLUSÃO}

Este artigo procurou demonstrar que a comunicação mediada assume importância cada vez maior no cotidiano social. Através dos veículos de mídia, a sociedade toma parte dos acontecimentos e das formações e transformações que ocorrem no mundo contemporâneo. Evidente que existem deficiências relativas aos aspectos ideológicos, de manipulação ou mesmo de formas de produção de conteúdo. Mesmo fazendo tais considerações, ainda é a melhor maneira de conhecer e formar opinião sobre os mais diferentes aspectos. Também é de forma mediada, seja dos veículos de comunicação de massa ou aqueles dirigidos para determinadas áreas, que no campo profissional as diferentes áreas se mantêm informadas sobre a atualidade do setor, novas tecnologias, legislação etc.

Para melhor compreensão do meio rural, tendo como recorte o ambiente ponta-grossense, fica claro que o agricultor familiar diferencia-se do grande produtor por suas características. O local em que vive é também onde trabalha e produz, e produzir é algo essencialmente ligado à sua permanência no meio rural. Ele desenvolve sua atividade basicamente com a mão de obra da família e planta e colhe para o consumo e para a venda, configurando-se dentro dos conceitos de Rubelo (2001). Também não se pode pensar em um agricultor familiar como público homogêneo. Características individuais diferenciam as famílias, sendo possível pensar em dezenas de grupos, com costumes próprios, produção, tradições, culturas, entre outros aspectos.

$\mathrm{O}$ agricultor familiar precisa estar interado de tudo o que acontece. É a necessidade de novos conhecimentos aliados aos tradicionais, como desta- cam Grossi e Silva (2002). Seria exagero dizer que as dificuldades do pequeno produtor e o êxodo rural ocorrem por conta de ele não fazer uso dos produtos de mídia de forma sistemática. Outros fatores muito mais relevantes, como a opção dos governantes pela agroindustrialização e produção de grãos, foram determinantes na exclusão no campo. Mas é possível que um maior grau de informação possa ajudar nas tomadas de decisões na agricultura familiar, ou seja, ser uma ferramenta eficaz, como destaca Bordenave (1985). Nesse aspecto, a mídia se mostra importante.

Não há, entre os pequenos produtores, uma formação cultural/educacional focada na centralidade da informação oferecida a partir dos produtos de mídia e os próprios meios de comunicação de massa não oferecem um produto que os tornem fundamentais para o dia a dia. Se houver um entendimento de que a comunicação merece um espaço maior na prática cotidiana rural, tanto por parte dos meios acadêmicos como dos setores governamentais, é preciso que a agricultura familiar seja mais orientada para as possibilidades existentes no conhecimento midiático. $\mathrm{O}$ trabalho intelectual pode, então, ser tão importante como plantar ou colher bem. Com um nível de esclarecimento mais elevado, o próprio produtor pode exigir uma comunicação rural mais eficaz e de qualidade.

Tais mudanças não são impossíveis, se lembrarmos que o agricultor familiar não está totalmente fechado a novidades, ainda que a tradição, o conhecimento e costumes repassados de geração para geração sejam mais importantes para ele. As duas relações, novo conhecimento e patrimônio cultural, podem ser fundamentais na continuidade e progresso da pequena propriedade.

As formas mediadas são cada vez mais usadas. Os meios de comunicação podem oferecer importantes respostas para os anseios da sociedade, inclusive no campo. Produzir apenas por hábito, sem conhecimento, é cada vez mais difícil e o produtor necessita dos meios de informação. Os processos de comunicação existem há séculos, mas a partir do século XX se intensificaram. As relações se dão cada vez mais a distância, através de processos midiáticos, e os acontecimentos externos interferem nos processos internos, mesmo nas menores localidades. Assim, diversos fatores formam as relações da agricultura familiar e a busca de conhecimento é importante para o trabalho e permanência no campo. 
Mas a relação com a atividade depende de uma produção atenta a tal público. Como demonstrado por Sousa (2002), há poderes simbólicos que interferem diretamente no agendamento das notícias, devido à complexidade de espaços e grupos. É no seio das mediações destacadas por Sousa (2002) que ocorre a produção da mídia, da qual o leitor ou espectador é fonte e receptor.

A comunicação rural tem mudado ao longo do tempo. Se no início era voltada para as comunidades rurais, apenas, depois o foco mudou para a produção. Nos anos 1970 e 1980, a grande mídia descobriu o mundo rural e foi abrindo espaço cada vez maior, interessada em ampliar a audiência ou as vendagens e obter lucro, além de transmitir as ideologias dominantes, como bem explica Oliveira (1989).

A comunicação rural para a agricultura familiar precisa conhecer quem é o público de demanda da sua produção e suas necessidades. Também deve ir além dos aspectos meramente produtivos. Saúde, educação, conservação do meio ambiente são temas que devem fazer parte da pauta cotidiana dos meios informativos. A falta de uma visão mais global de todo o universo rural pode ser um dos motivos para o pequeno produtor não definir a comunicação como uma ferramenta sistemática nas suas atividades. Mas se ele encontrar sentido prático, pode interagir de forma diferente.

Ainda assim, a primeira conclusão à que se chega no presente artigo é de que o agricultor familiar, de certa forma, utiliza produtos midiáticos feitos para o meio, uma vez que 45 dos 60 entrevistados acompanham algum tipo de comunicação rural. Portanto, ele tem conhecimento de muito do que se produz.

Mas se o agricultor familiar tem conhecimento e até acompanha os noticiários, fica claro que os produtos midiáticos não são considerados uma ferramenta necessária e sistemática na vida profissional de tal público. Mais da metade (61,7\%) acompanha preços, porém, com o objetivo principal de saber qual o valor de sua produção na hora de vender e não como ferramenta de tomada de decisão ou planejamento. Os próprios veículos não servem de parâmetro - a maioria dos agricultores diz que acompanha o mercado pelo rádio e televisão e a pesquisa sobre os meios de comunicação mostrou que não há uma cobertura eficaz, que aborde todos os campos e que faça uma análise dos mercados para o agricultor familiar.
A questão dos preços pode ser pontual, mas, mais da metade $(51,5 \%)$ informou que não costuma usar as informações do meio, mesmo que acompanhem noticiários rurais. $\mathrm{O}$ que reforça o resultado de que a mídia não está presente nas principais decisões do agricultor familiar é o fato de ela não ser lembrada como uma maneira de decidir o que e quando produzir. Por outro lado, é instigante observar que 88,4\% dos entrevistados acreditam que a produção midiática é importante. A resposta pode ser apenas retórica, como muitas no seio social, como, por exemplo, considerar a reforma agrária necessária ou entender que é preciso se proteger para aplicar agrotóxicos. O que falta é colocar o reconhecimento da importância da comunicação em prática.

A falta de uso da comunicação como ferramenta sistemática na atividade econômica da agricultura familiar se dá por vários fatores, conforme indicativos que apareceram na pesquisa empírica. Pelas respostas dos entrevistados, não passa pela técnica adotada pela mídia, ao menos em se tratando dos produtos midiáticos que eles utilizam, uma vez que $66,7 \%$ consideram a linguagem de fácil entendimento. Falta de hábito e critérios de noticiabilidade que não atendem às demandas de tal público podem ser destacados como alguns dos fatores centrais.

$\mathrm{O}$ agricultor familiar tem uma formação própria, com cultura e interesses próprios, a partir dos quais, conforme demonstrou a pesquisa empírica, a produção midiática rural tem sido utilizada mais como "instituição de lazer" ou preenchimento do tempo, como curiosidade, do que como trabalho intelectual. As tomadas de decisões estão mais ligadas a fatores tradicionais.

A noticiabilidade da mídia para o meio rural, em qualquer dos meios verificados, confirma a tendência mercadológica, na qual se busca vender produtos e ideias dominantes, sendo relevante o fato de a movimentação social nortear os meios. O recorte do campo é mercadológico, focado no desempenho do agronegócio, e idealizado.

Portanto, o não uso dos produtos midiáticos de forma sistemática pelos agricultores familiares pode ser entendido na complexidade das relações entre o pequeno produtor rural e os meios de comunicação, e não apenas nas limitações produtivas e de receptividade. São os dois aspectos, juntos, que sugerem pistas para tal compreensão e que podem ser frutos de novos estudos sobre o problema. 


\section{REFERÊNCIAS}

BARDIN, Laurence. Análise de conteúdo. Lisboa: Edições 70, 1977.

BORDENAVE, Juan Ernesto Diaz. O que é comunicação rural. 2. ed. São Paulo: Brasiliense, 1985.

BOTEON, Margarete. Mercado de informação digital agroeconômica. 2004. 90 p. Tese (Doutorado em Ciências Economia Aplicada). Escola Superior de Agricultura Luiz de Queiroz (USP), Piracicaba.

CALlOU, Ângelo Brás Fernandes. Comunicação rural, tecnologia e desenvolvimento local. São Paulo: Intercom, 2002.

CANCLINI, Néstor García. Consumidores e cidadãos: conflitos multiculturais da globalização. 4. ed. Rio de Janeiro: Editora UFRJ, 1999.

COELHO NETTO, José Teixeira. Semiótica, informação e comunicação. 6. ed. São Paulo: Perspectiva, 2003.

CORCUFF, Philippe. As novas sociologias: construções da realidade social. Tradução de Viviane Ribeiro. Bauru: Edusc, 2001.

DEFLEUR, Melvin L.; BALL-ROKEACH, Sandra. Teorias da comunicação de massa. Tradução de Octaviano Alves Velho. 5. ed. Rio de Janeiro: Jorge Zahar, 1993.

FELICIANO, Antonio Marcos et al. Impacto da tecnologia da informação sobre o processo decisório do agricultor familiar. Florianópolis: Instituto Cepa/SC, 2004.

FERNÁNDEZ, Francisco; AMTMANN, Carlos. El modelo de difusión y el desarrollo rural: algunas consideraciones críticas. Disponível em: <www.humanidades.uach.cl/ camtmann/carpeta/modelo.doc>. Acesso em: 8 de mai. 2007.

FIGUEIREDO, José Carlos; GIANGRANDE, Vera. Comunicação sem fronteiras: da pré-história à era da informação. São Paulo: Gente, 1999.

GONÇALVES, Elizabeth Moraes. A construção do discurso sobre o meio rural: uma análise do programa "Globo Rural". Comunicação em Agribusiness \& Meio Ambiente, v. 2, n. 2, jul. 2005. Disponível em <http://www.agricoma.com.br/ rev2artigoBethGonçalves.htm>. Acesso em: 15 jan. 2007.
GROSSI, Mauro Eduardo Del; SILVA, José Graziano. Novo rural - uma abordagem ilustrada. Londrina: Iapar, 2002.

KELLNER, Douglas. A cultura da mídia: estudos culturais, identidade e política entre o moderno e o pós-moderno. Tradução de Ivone Castilho Benedetti. Bauru: Edusc, 2001.

LAMARCHE, Hugues. (Coord.) A agricultura familiar: comparação internacional. Tradução de Ângela Maria Naoko Tijuwa. Campinas: Unicamp, 1993.

LUNA, Sérgio Vasconcelos de. Planejamento de pesquisa: uma introdução - elementos para uma análise metodológica. São Paulo: EDUSP, 1996.

MARTINS, José de Souza. As coisas no lugar: da ambiguidade à dualidade na reflexão sociológica sobre a relação cidade-campo. In: (Org). Introdução crítica à sociologia rural. São Paulo: Hucitec, 1981. p. 11-40.

OLIVEIRA, Valdir de Castro. Integração e subordinação do rural à indústria da cultura. In: MELO, José Marques de (org.). Comunicação na América Latina: desenvolvimento e crise. Campinas: Papirus, 1989. p. 149-166.

ORTRIWANO, Gisela Swetlana. A informação no rádio. Os grupos de poder e a determinação dos conteúdos. 3. ed. São Paulo: Summus, 1985.

RICHARDSON, Roberto Jarry. Pesquisa social: métodos e técnicas. 2. ed. São Paulo: Atlas, 1989.

RUBELO, João Geraldo Nunes. As relações sociais e a pequena produção agrícola no município de Jales-SP. In: Economia e pesquisa: revista da Faculdade de Ciências Econômicas de Araçatuba. Araçatuba, mar. 2001. p. 63-81.

SCHNEIDER, Sérgio. A Pluriatividade na Agricultura Familiar. Porto Alegre: UFRGS, 2003.

SOUSA, Mauro Wilton de. Recepção e comunicação: a busca do sujeito. In: (org). Sujeito, o lado oculto do receptor. São Paulo: Brasiliense, 2002.

THOMPSON, John B. A mídia e a modernidade. Uma teoria social da mídia. 4. ed. Petrópolis: Vozes. 2002.

Recebido em abril de 2012. Aceito em setembro de 2012. 